\title{
Model of Education Quality Management of Traditional Islamic Boarding Schools in Aceh
}

\author{
Zahraini \\ Universitas Negeri Medan \\ Medan, Indonesia \\ Zahraini_za@yahoo.co.id
}

\author{
Benyamin Situmorang \\ Universitas Negeri Medan \\ Medan, Indonesia \\ Benyaminsitumorang@gmail.com
}

\begin{abstract}
Traditional Islamic boarding school is the main educational institution in culture in the province of Aceh. The objective of this research was to identify the models of education quality management of traditional Islamic boarding schools in Aceh. This qualitative research method was conducted by doing observation, interview, and documentation.The results indicated that there was no accreditation program, no curriculum of social and political sciences, and no Arabic language liability. so the students in the traditional Islamic boarding schools have very little ability to speak Arabic language. The students learn after Fajr prayer, after Dhuhr prayer, Maghrib prayer, and after Isha prayer.The lessons from the first until the fourth grade included Islamic Texts and Syntax and the lessons for the fifth and sixth grade included Fiqh, Oneness of God, and Sufism. It can be concluded that the components of quality management of education in traditional Islamic boarding schools should be considered. The components consist of foundation, goals, curricula, teachers' professionalism, teaching methodology, infrastructure and facilities, evaluation, and budget allocation. Nowadays, the government are paying enough attention to those schools. There is even an Education Board for Islamic Schools. This board is expected to enhance the educational quality of the schools.
\end{abstract}

\section{Keywords-Quality Management; Traditional Islamic}

\section{INTRODUCTION}

Dayah (traditional Islamic boarding school) is the main educational institution in culture in the province of Aceh, for hundreds of years,Dayah educational institutions have several disciplines and have produced many religious experts. Mubarak in Journal of Management Education, Volume I, Issue I, ISSN 977-2442404, explains: Islamic education management is a process of structuring/managing Islamic education institutions that involve human resources to achieve educational goals effectively and efficiently. Qanun Province of Nanggroe Aceh Darussalam No. 23 of 2002 concerning the implementation of education in NAD in article 16, paragraph 1 stated that the Islamic boarding school/Islamic boarding school is an Islamic education institution with a cottage (rangkang) system led by moslem scholar (ulama), organized by foundations, social institutions, individuals, and/or the government. And paragraph 2 also mentions that dayah (pesantren) education consists of Salafiyah (traditional) dayahwho do not hold a madrasah education program system, Integrated Dayah which organizes various madrasah education
programs.Modern Islamic Boarding Schooland traditional Islamic Boarding School are in a complex that has buildings other than student dormitories and teungku/teacher houses, madrasah buildings in sports fields, canteens, cooperatives, agricultural land or farmland. The founders and dayah caregivers were role models in the Acehnese society. The moslem scholar (teungkudayah/ulama) lead the community both socially and politically. Dayah scholars give directions in terms of their knowledge to the community and government because the moslem scholar are the main role models in the province of Aceh.

Problems in traditional Islamic boarding school (dayah) in Aceh, in general teachers in traditional Islamic boarding school cannot communicate using Arabic, so the student also cannot communicate in Arabic. Traditional Islamic boarding school excel in learning Islamic laws and mastering the yellow book (the book contains Islamic knowledge). Mukhibat in the Karsa journal Social and Islamic Culture Vol. 23 no. 2 December 2015: 1777-192, explained the Islamic boarding school's response to modern culture can be divided into two types, such as first, the pure salafiIslamic boarding school, which is the Islamic boarding school which has retained the yellow book as the main literature in the curriculum.

This type of Islamic boarding school is relatively rare and does not carry out formal education. The standard of graduation and success of a student is determined by the ability to master the yellow book. The quality of education in traditional Islamic boarding schoolneeds to be developed maximally, in traditional Islamic boarding school, an accreditation program needs to be developed. According to Edward (2006) An institution must have a clear policy statement on quality. quality policy is a statement of commitment submitted by the institution.

From the above background, it can be concluded the importance of developing quality management of Traditional Islamic boarding schools or dayah in Aceh Province, in accordance with the principles of education quality management. 


\section{RESEARCH METHODOLOGY}

\section{A. Research approach}

The approach in this study is a qualitative approach through observation, interviews, and documentation. Qualitative research is often called naturalistic research methods because the research is carried out under natural conditions. According to Sugiyono (2013: 13-14) qualitative research can be interpreted as a research method based on the philosophy of postpositivism, used to examine the condition of natural objects, (as opposed to experiments) where researchers are key instruments.

\section{B. Research subject}

Research subjects are all research objects which include material, tools, and all personnel involved in management at the Islamic boarding school (dayah). In accordance with the focus of research on quality management models at dayah, the subjects in this study are leaders, educators, staff and students (santri) dayah to see firsthand the model of dayah quality management.

\section{Data collection technique}

Data collection procedures used in this research are observation, interview, documentation techniques, these three methods are carried out with the intention to obtain truly reliable, deep and objective data and information. Riduwan (2013: 97) suggests that: data collection methods are techniques or methods that can be used by researchers to collect data. Methods (methods or techniques) designate an abstract word that is not materialized in objects, but can only be seen using: questionnaires, interviews, observations, tests, documentation and others. Researchers can use one or a combination depending on the problem at hand.

\section{Data analysis technique}

In qualitative research, data is obtained from various sources using data collection techniques. The data obtained are generally qualitative data, although they do not reject quantitative data, so the data analysis technique used has no clear pattern. In the case of Bogdan qualitative data analysis (Sugiyono, 2009: 334) states that "Data analysis is the process of systematically searching and arranging the interview transcripts, fieldnotes, and understanding of them and to enable you to present what you have discovered to others". Based on that matter it can be stated that data analysis is the process of systematically finding and compiling data obtained from interviews, field notes, and documentation, by organizing data into categories, describing it into units, synthesizing, compiling into patterns, choosing which ones are important and will be learned, and making conclusions so that they are easily understood by themselves and others.

\section{E. Building Research Validity}

To build the validity of the research, referring to the concept of trustworthiness Lincoln and Guba comparing quantitative and qualitative research, internal validity compared with trust (credibility), external validity compared to transferability, reliability compared to certainty (conformability). So to build the validity of all research, the examination techniques used are based on Lincoln and Guba, namely by testing credibility, transferability, dependability, conformability.

\section{RESEARCH RESULT}

The results of the study are based on observation, interviews and documentation about the quality assurance model at the dayah, the head of the dayah said: "I do not understand about quality assurance at dayah, I only expect students to master Islamic laws and yellow books and be able to preach".

The leaders also explained: the management at Dayah has not implemented integrated quality management, and our dayah management is traditional. A dayah teacher explained: students were taught to preach using the Acehnese language and Indonesian language and did not use foreign languages, namely English or Arabic.

Regarding the teaching schedule, the dayah leader explained: Schedule to teach at the dayah after sunset and after Isha prayer. One teacher teaches one class for all lessons, the students also have a session to repeat their own lessons, in addition to the most diligent class, the students are usually more mastering the study material. If quality can be managed, then quality must also be measurable. Quality here is also the advantage of "excellence" or the best results.

However, quality in educational institutions, especially Islamic education institutions in traditional Islamicboarding schoolis not something that happens suddenly. There is a quality trilogy developed, such as: 1) quality planning, 2) quality control, 3) quality improvement. However, integrated quality (total quality) is something that is achieved continuously. In accordance with the opinion of Juran (2010: 124) about quality, among others: 1) achieving quality is a process that does not know the end, 2) quality improvement is a continuous process, not a one-way program, 3) quality requires leadership from school board members and administrator, 4) mass training is a pre-quality requirement, 5) everyone in the school must get training.

There are several aspects that need to be better managed by the Islamic boarding school, among others: 1) planning and evaluation, 2) curriculum, 3) the process of learning, 4) workforce, 5) equipment and completeness, 6) finance, 7) student services, 8) relationship between Islamic boarding schools and community, and 9) Islamic boarding school climate. In accordance with the principles of school-based quality improvement, such as: 1) focus on quality or quality, 2) planning and decision making starting from the bottom (bottom-up planning and decision making), 3) transparent management, 4) community empowerment, 5) continuous quality improvement.

Islamic boarding school, most of them are still struggling with the old style, although on the otherhand it is very good especially in moral education and social change that is too fast, making Islamic boarding school look outdated. 


\section{CONCLUSION}

The quality management at dayah is very important from various components. The component covers the foundation, objectives, curriculum, competence and professionalism of teachers, patterns of teacher and student relations, learning methodology, infrastructure, evaluation and financing. The Dayah in Aceh Province has become a reference point for every social and political problem in the Acehnese community, so the government's attention to these Islamic boarding schoolsare better so that the Aceh province established an office regarding Islamic boarding school in Aceh Province government (Dayah office). It is expected that the Dayahoffice is able to solve all the problems that exist in the dayah because as long as the government does not truly realize the views in quality management in traditional dayah, we can be sure that the quality of education in the dayah is stagnant and even decreases.

\section{ACKNOWLEDGEMENT}

Thanks to all parties who have provided moral and material assistance, especially to: all parties who have provided moral and material assistance, especially to: the international advisory board/Scientific committee by Dr.RahmatHusein, M. Ed, Dr.JuniAstel Raja Gukguk, M.Sc., Dr.RachmatMulyani, M. Si and Dr. E. Elvis Napitulu, M. S. Thank you deeply to Indexed by Thomson Reuters,Compendex, NKI Scholar, and Google Scholar and author's respect for the entire academic community of the Medan State University Graduate Program and Murdoch University Perth, Western Australia. Thank you also to the author, to LPDP, Ministry of Finance of the Republic of Indonesia for funding the author's education fund for the International Seminar. Finally, for the service and kindness of the parties who have helped the completion of this article and the implementation of International seminars may receive multiple replies from God Almighty and hopefully this article will be useful for readers in general and especially readers in the field of Administration/management education.

\section{REFERENCES}

[1] A,Suharsimi "ProsedurPenelitianSuatuPendekatanPraktik," Jakarta, 2010. pp. $45-46$

[2] B. R. Walter and Gall, "Educational Research: an Indroduction".(7 thed), New York: Longman, Inc 2003, pp 10-11.

[3] E. Sallis, "Total Quality Management in Education," Jogyakarta: IRCiSoD.2006.pp 89-100.

[4] F. DehzadehAlireza, Mahmod Reza RobatKarim, Mehdi Roshanfekr, JamshidAzizi, FarrokhLeghaHatami, "European Online Journal of Natural and Social Science,” IEEE Transl. J. Magn. Japan, vol. 2, pp. 740-741, August 2013. pp 20-21

[5] F. Akhtar, Z. UllahandMemon,'Journal Of Quality Technology Management". Volume III, Issue II, 2007. pp 13-14

[6] H. Mohammed, In' airatandA.H Al-Kassem, "International Journal of Human ResorceStudies”. Vol. 4, No. 3. 2014.

[7] J, Joseph M and D. F. Joseph A, "Juran's Quality HandBook". Sicth Edition United of America The McGraw-Hill Companies, Inc. All rights reserved. 2010.

[8] L, Hasan, "MemperdayakanSistemPendidikanIslam". Bandung: Logos WacanaBaru. 1999.

[9] L, Robert N, "Management, Concepts, Aplication, Skill Development" United States Of America: International Thomson Publiching.1997.

[10] Mukhibat. "Karsa journal Social and Islamic Culture" Vol. 23 no. 2 December 2015: 1777-192

[11] PermendagriNomor 95 Tahun 2016 TentangPerangkat Daerah. 2016.

[12] Qanun No. 23 tahun 2002 tentangPenyelenggaraanPendidikan di Aceh. 2002

[13] Sugiyono, "MetodePenelitianBisnis (pendekatanKuantitatif, Kualitatifdan R\&D”. Bandung: Alfabeta. 2009. 